\title{
Reversible renal failure after combined treatment with enalapril and frusemide in a patient with congestive heart failure
}

\author{
CHRISTIAN FUNCK-BRENTANO,* GILLES CHATELLIER, * \\ JEAN-MICHEL ALEXANDRE $\dagger$ \\ From * Service d'hypertension artérielle and †Département de Pharmacologie Clinique, Hopital Broussais, \\ Paris, France
}

SUMMARY A patient with congestive heart failure and moderate renal insufficiency developed severe reversible non-oliguric renal failure while on frusemide and enalapril. Renal failure developed when enalapril was given in the presence of pronounced sodium depletion. When positive sodium balance was restored the plasma creatinine concentration began to fall while angiotensin converting enzyme inhibition remained effective and blood pressure was stable.

These observations suggest that the degree of sodium depletion plays an important role in the tendency for angiotensin converting enzyme inhibitors to induce renal failure in patients with congestive heart failure and moderate renal insufficiency. Restoration of a positive sodium balance promotes the recovery of renal function after the combined administration of angiotensin converting enzyme inhibitors and diuretics.

Treatment of congestive heart failure with vasodilators, including angiotensin converting enzyme inhibitors, produces both clinical and circulatory improvement. ${ }^{12}$ Recently, however, it has become apparent that renal function may be adversely affected by inhibition of the angiotensin converting enzyme in the treatment of congestive heart failure ${ }^{34}$ or renovascular hypertension. ${ }^{56}$ Disturbances in glomerular autoregulation due to inhibition of angiotensin converting enzyme, ${ }^{7}$ either alone or in combination with diuretics, ${ }^{38}$ and hypotensioninduced renal hypoperfusion ${ }^{4}$ have been regarded as the main factors that contribute to impaired renal function during treatment with angiotensin converting enzyme inhibitors. Enalapril, a new angiotensin converting enzyme inhibitor, with long lasting action, has beneficial haemodynamic effects in the management of heart failure. ${ }^{2}$

We report here the case of a patient with congestive heart failure who developed severe, reversible non-oliguric renal failure while on frusemide and enalapril. His clinical course provides an opportunity to examine the relative importance of

Reprints will not be available from the authors. hypotension, angiotensin converting enzyme inhibition, and sodium depletion in the deterioration and recovery of renal function.

\section{Case report}

A 78 year old man with mild renal insufficiency had been successfully treated with digitoxin and diuretics for dilated cardiomyopathy (New York Heart Association grade III) from early 1982 until April 1984. Heart failure then became resistant to treatment and captopril ( $50 \mathrm{mg}$ three times daily) was introduced. Dyspnoea improved but plasma creatinine rose slowly from 157 to $330 \mu \mathrm{mol} / 1$ between April and December 1984. Treatment with captopril was stopped because he lost his sense of taste, and was then given enalapril (20 $\mathrm{mg}$ per day) together with digitoxin $(0 \cdot 10 \mathrm{mg}$ every two days) and slow release frusemide ( $60 \mathrm{mg}$ per day). This regimen was introduced on 26 December 1984.

Renal function remained stable until the patient was admitted to another hospital on 7 January 1985. His creatinine clearance on admission was 20 $\mathrm{ml} / \mathrm{min}$. Administration of enalapril was stopped on 11 January, and frusemide ( $40 \mathrm{mg}$ twice daily) was 

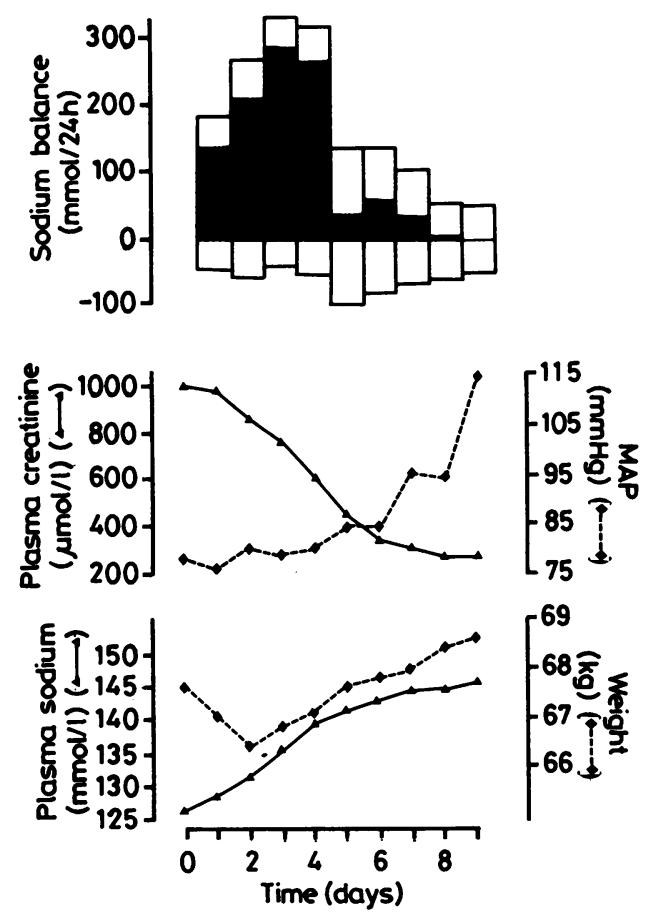

Figure The clinical course of the patient. MAP, mean arterial pressure (values are the means of three daily measurements of supine blood pressure); sodium balance, dark columns represent the difference between estimated sodium intakes and losses. A positive free water clearance on days 1 and 2 explains the weight loss that occurred despite $a$ positive sodium balance.

started. On the same day renal echographic examination showed no dilatation of the calices, and the left and right kidneys were 9 and $10 \mathrm{~cm}$ long respectively. Between 7 January and 19 January diuresis increased and the patient lost $2.5 \mathrm{~kg}$ in weight; no fall in blood pressure was observed, but plasma creatinine rose from 360 to $460 \mu \mathrm{mol} / \mathrm{l}$. He was discharged on 19 January, and treated with frusemide ( $40 \mathrm{mg}$ twice a day), enalapril (20 $\mathrm{mg}$ per day), and digitoxin ( $0.10 \mathrm{mg}$ every two days). His supine blood pressure on discharge was 130/70 $\mathrm{mm} \mathrm{Hg}$. On 23 January his plasma creatinine concentration had risen to $1000 \mu \mathrm{mol} / \mathrm{l}$ and he was referred to our hospital.

On arrival he was well, but had mild clinical signs of dehydration. The pulse rate was 120 beats/min, blood pressure was $120 / 64 \mathrm{~mm} \mathrm{Hg}$ supine and 92/62 $\mathrm{mm} \mathrm{Hg}$ standing. Otherwise physical examination was normal. A chest radiograph showed cardiomegaly with a cardiothoracic ratio of 0.55 but no sign of pulmonary oedema. Renal echography showed no change from the previous examination. Blood urea nitrogen was $56.2 \mathrm{mmol} / \mathrm{l}$, creatinine $1005 \mu \mathrm{mol} / \mathrm{l}$, sodium $127 \mathrm{mmol} / \mathrm{l}$, potassium $4.6 \mathrm{mmol} / \mathrm{l}$, carbon dioxide $15.3 \mathrm{mmol} / 1$, total proteins $7.7 \mathrm{~g} / \mathrm{dl}$, calcium $2.28 \mathrm{mmol} / \mathrm{l}$, and glucose $6.5 \mathrm{mmol} / 1$. His haematocrit was $41 \%$, and haemoglobin was $12.8 \mathrm{~g} / \mathrm{dl}$. All drugs were discontinued and the patient was given bicarbonate and intravenous saline. The Figure shows the time course of changes in his weight, mean arterial blood pressure, and plasma sodium and creatinine during the days after admission. The initial 24 hour diuresis was $1300 \mathrm{ml}$ and remained above $1000 \mathrm{ml}$ thereafter. On the first day, plasma renin activity while supine was $33.5 \mathrm{ng} / \mathrm{ml} / \mathrm{h}(25.7$ $\mathrm{mmol} / \mathrm{l} / \mathrm{h}$ ) (normal range in sodium replete state 0.35-1.30 ng angiotensin $\mathrm{I} / \mathrm{ml} / \mathrm{h} \quad(270-1002$ $\mathrm{pmol} / \mathrm{l} / \mathrm{h})$ ) and plasma aldosterone while supine was $3.5 \mathrm{ng} / \mathrm{dl}$ (normal range in the sodium replete state 5-12 ng/dl (138.5-332.4 pmol/1)). On the first two days, the plasma enalaprilic acid concentration was very high $(597 \mathrm{ng} / \mathrm{ml}$ and $392 \mathrm{ng} / \mathrm{ml}$ respectively; mean (SD) peak value concentration in hypertensive patients with normal renal function who had taken $20 \mathrm{mg}$ enalapril per day for three weeks in our laboratory was $75.6(25 \cdot 8) \mathrm{ng} / \mathrm{ml})$. Plasma converting enzyme activity on the second day was significantly reduced at $1.9 \mathrm{mU} / \mathrm{ml}$ (normal: $30.8(7.5) \mathrm{mU} / \mathrm{ml}$ ). During the following days the patient's condition improved on water restriction and intravenous bicarbonate and saline. By day eight creatinine clearance was $25 \mathrm{ml} / \mathrm{min}$. Mild intermittent proteinuria $(<150$ $\mathrm{mg} / 24 \mathrm{~h}$ ) was observed but no pyuria, haematuria, or bacteriuria occurred during the patient's stay at this hospital. Renal arteriography showed normal renal arteries; a renal biopsy was not performed. On day 11 the patient experienced dyspnoea, and was given diuretics, digitoxin, and isosorbide dinitrate. Later enalapril ( $5 \mathrm{mg}$ per day) was added. Five, six, and seven days after enalapril was started the plasma concentration of enalaprilic acid immediately before drug intake was $23 \mathrm{ng} / \mathrm{ml}$, and plasma converting enzyme activity was $6.6 \mathrm{mU} / \mathrm{ml}$. The patient was discharged on isosorbide dinitrate (60 $\mathrm{mg}$ per day), digitoxin ( $0 \cdot 10 \mathrm{mg}$ every two days), enalapril ( $5 \mathrm{mg}$ per day), and frusemide ( $40 \mathrm{mg}$ every two days). His plasma creatinine remained stable at $265 \mu \mathrm{mol} / 1$ for the next two months.

\section{Discussion}

This patient developed non-oliguric acute on chronic renal failure during combined treatment with frusemide and enalapril. Renal function slowly deteriorated before the introduction of the angiotensin converting enzyme inhibitor. Because there was no echographic evidence of obstructive uropathy or a history of chronic nephrotoxic drug adminis- 
tration, the underlying renal disease was presumed to have been nephroangiosclerosis.

In this patient with normal renal arteriography and congestive heart failure, enalapril induced acute renal insufficiency when it was administered after sodium depletion had become pronounced. This suggests that the degree of sodium depletion may play a major role in the propensity of angiotensin converting enzyme inhibitors to induce renal failure. This hypothesis accords with the results of Mujais et $a l$, who found that renal plasma flow and glomerular filtration rate dropped considerably after the first dose of captopril in patients with congestive heart failure who were given diuretics. ${ }^{3}$ Creager et al obtained contrasting results in the salt replete state. ${ }^{9}$ The renin-angiotensin system plays a major role in renal adaptation to sodium depletion ${ }^{710}$ and to congestive heart failure. ${ }^{11}$ Preservation of glomerular filtration rate by angiotensin II mediated constriction of glomerular efferent arterioles may be the basis of the adaptation to low renal perfusion pressure. ${ }^{7}$ Angiotensin converting enzyme inhibitors enhance the vasodilatatory actions of prostaglandins and bradykinin ${ }^{12}$ and may also contribute to a decreased rate of glomerular filtration. ${ }^{7}$

Arterial hypotension leading to renal hypoperfusion and failure cannot be excluded in our patient. Nevertheless, renal failure on a combination of diuretics and angiotensin converting enzyme inhibitors has been reported to occur independently of a drop in blood pressure. ${ }^{38}$ Finally, the underlying renal disease may also have been an important factor favouring renal failure in the face of angiotensin converting enzyme inhibition and sodium depletion.

In view of the recovery of renal function in our patient, we believe that the positive sodium balance played a major role. The plasma creatinine concentration began to fall on day two (Fig.) even though inhibition of angiotensin converting enzyme was still effective, as shown by the very low plasma converting enzyme activity. Moreover, the concentration of plasma enalaprilic acid (the active metabolite of enalapril) remained high $(392 \mathrm{ng} / \mathrm{ml}$ ) on day two. Inhibition of plasma converting enzyme activity is thought to be greatest when plasma enalaprilic acid concentration is $>20 \mathrm{ng} / \mathrm{ml} . .^{13}$ After the resumption of enalapril treatment in our patient, this concentration remained above this threshold without impairing renal function when a new sodium balance had been reached.

Since the mean arterial blood pressure did not change during the first four days (Fig.), it is unlikely that the fall in plasma creatinine was induced by a blood pressure related increase in renal blood flow.

This case suggests that the level of sodium depletion is a major factor in determining the ability of angiotensin converting enzyme inhibitors to induce acute renal insufficiency in congestive heart failure. In cases when such heart failure is treated by a combination of angiotensin converting enzyme inhibitors and diuretics, the restoration of a positive sodium balance is the main factor in restoring renal function after renal failure.

We are indebted to Dr John Chapman for reviewing the typescript.

\section{References}

1 Dzau VJ, Colucci WS, Williams GH, Curfman G, Meggs L, Hollenberg NK. Sustained effectiveness of converting enzyme inhibition in patients with severe congestive heart failure. $N$ Engl f Med 1980; 302: 1373-9.

2 Fitzpatrick D, Nicholls MG, Ikram H, Espiner EA. Haemodynamic, hormonal, and electrolyte effects of enalapril in heart failure. Br Heart $\mathcal{F}$ 1983; 50: 163-9.

3 Mujais SK, Fouad FM, Textor SC, et al. Transient renal dysfunction during initial inhibition of converting enzyme in congestive heart failure. Br Heart $\mathcal{F} 1984$; 52: 63-71.

4 Pierpont GL, Francis GS, Cohn JN. Effect of captopril on renal function in patients with congestive heart failure. Br Heart f 1981; 46: 522-7.

5 Aldigier J-C, Plouin P-F, Guyenne TT, Thibonnier $\mathrm{M}$, Corvol P, Ménard J. Comparison of the hormonal and renal effects of captopril in severe essential and renovascular hypertension. Am $\mathcal{f}$ Cardiol 1982; 49: 1447-52.

6 Hricik DE, Browning PJ, Kopelman R, Goorno WE, Madias NE, Dzau VJ. Captopril-induced functional renal insufficiency in patients with bilateral renal-artery stenoses or renal-artery stenosis in a solitary kidney. $N$ Engl f Med 1983; 308: 373-6.

7 Blythe WB. Captopril and renal autoregulation. $N$ Engl f Med 1983; 308: 390-1.

8 Murphy BJ, Whitworth JA, Kincaid-Smith P. Renal insufficiency with combinations of angiotensin converting enzyme inhibitors and diuretics. $\mathrm{Br}$ Med $\mathcal{F} 1984$; 288: 844-5.

9 Creager MA, Halperin JL, Bernard DB, et al. Acute regional circulatory and renal hemodynamic effects of converting-enzyme inhibition in patients with congestive heart failure. Circulation 1981; 64: 483-9.

10 Hall JE, Guyton AC, Smith MJ Jr, Coleman TG. Chronic blockade of angiotensin II formation during sodium deprivation. Am F Physiol 1979; 237: F424-32.

11 Dzau VJ, Colucci WS, Hollenberg NK, Williams GH. Relation of the renin-angiotensin-aldosterone system to clinical state in congestive heart failure. Circulation 1981; 63: 645-51.

12 Moore TJ, Crantz FR, Hollenberg NK, et al. Contribution of prostaglandins to the antihypertensive action of captopril in essential hypertension. Hypertension 1981; 3: 168-73.

13 Biollaz J, Schelling JL, Jacot des Combes B, et al. Enalapril maleate and a lysine analogue (MK 521) in normal volunteers; relationship between plasma drug levels and the renin angiotensin system. Br $\mathcal{Y}$ Clin Pharmacol 1982; 14: 363-8. 